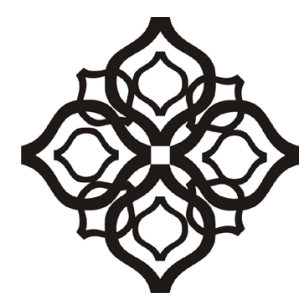

Shirkah

Journal of Economics and Business 


\section{Shirkah}

Journal of Economics and Business

Vol. 3, No. 2, May-August 2018

ISSN: 2503-4235 (p); 2503-4243 (e)

\section{Editor in Chief}

Dwi Condro Triono

\section{Managing Editor}

Jasanta Peranginangin

\section{Editorial Boards}

Abdul Azim Islahi,

Islamic Economics Institute, King Abdulaziz University, Saudi Arabia

Abu Umar Faruq Ahmad,

UBD School of Business and Economics Universiti, Brunei Darussalam

Cedomir Nestorovic,

ESSEC Business School Asia Pacific, Singapore

Fitri Wulandari,

Faculty of Islamic Economics and Business, IAIN Surakarta, Indonesia

Johan Fischer,

Department of Social Sciences and Business Roskilde Universitetscenter, Denmark Muhamed Zulkhibri,

Islamic Research and Training Institute, Islamic Development Bank, Saudi Arabia M. Kabir Hassan,

Department of Economics and Finance, University of New Orleans, United States Musa Asy'arie,

Faculty of Islamic Economics and Business, IAIN Surakarta, Indonesia Nunung Nurul Hidayah,

Aston Business School, Aston University, Birmingham, United Kingdom

Saim Kayadibi,

Department of Economics, Kulliyyah of Economics and Management Science, International Islamic University Malaysia, Malaysia 
Shaikh M Ghazanfar,

Departement of Economics, University of Idaho, Russian Federation

Sigit S. Wibowo,

Department of Management, Faculty of Economics and Business, Universitas Indonesia, Indonesia

Vihang R. Errunza,

Desmarais Global Finance Research Centre, Desautels Faculty and Management, McGill University, Canada

\section{Assistant to Editor}

M. Endy Saputro

M. Zainal Anwar

Shirkah Journal of Economics and Business is a peer-reviewed journal published three times a year (January-April, May-August and September-December) by Faculty of Islamic Economics and Business, Institut Agama Islam Negeri (IAIN) Surakarta Central Java, Indonesia. The main objective of Shirkah is to offer an academic space of exchange ideas and initiate the increase number of qualified article produced by postgraduate students, practitioners and academicians.

\section{Editorial Office}

Ruang Jurnal Shirkah

Lantai Dasar, Sayap Barat, Fakultas Ekonomi dan Bisnis Islam, IAIN Surakarta

Jln. Pandawa No. 1, Kartasura, Sukoharjo, Jawa Tengah Kode Pos. 57168

Phone (+62271) 781516 Fax: (+62271)782336

E-mail: shirkahjournal@iainsurakarta.ac.id; shirkahiainsurakarta@gmail.com Website: http://shirkah.or.id/ 


\section{Shirkah}

\section{Journal of Economics and Business}

Vol. 3, No. 2, May-August 2018

ISSN: 2503-4235 (p); 2503-4243 (e)

\section{Table of Contents}

\section{Articles}

Eko Fajar Cabyono

Lina Nugraha Rani

Macroprudential Policy on Sharia Banking Financing

The Indonesian Experience

Yulianti

Seeing a Buddhist Doing Business in Contemporary Indonesia An Interview with Mr. Sudhamek A.W.S

Fransisca Dwijayanti

Making Economics of Piety

Fashion, Lifestyle and Identity in Pop-Islamism Turn

Indah Piliyanti

Fintech Achieving Sustainable Development

The Side Perspective of Crowdfunding Platform

Taufik Nugroho

Aam S. Rusydiana

Macroeconomic Variables on Indonesian Sharia Capital Market

Hurdle Rate and Adverse Selection on Escalation of Commitment 


\title{
Making Economics of Piety \\ Fashion, Lifestyle and Identity in Pop-Islamism Turn
}

\author{
Fransisca Dwijayanti \\ Center for Religious and Cross-cultural Studies, \\ Sekolah Pascasarjana Multidisiplin, Universitas Gadjah Mada \\ dwijayanti.fransisca@gmail.com
}

\begin{abstract}
The emergence of young Muslims since the last decade has led Muslim industry to grow rapidly into the market bringing new social era of Islamic fashion. What is the role of religious piety boosting the production the Muslim fashion industry? This article argues that Muslim fashion have embodied within economic part of religion. In addition, this glowing of the industry has been supported by the blooming of such factors as media (Muslim magazines), Muslim designers, Muslim communities, and Muslim fashion stores. The industry of Muslim fashion ultimately becomes one of the most promising industries in fashion retail in Indonesia and other Muslim majority countries.
\end{abstract}

Keywords: Muslim fashion, lifestyle, market Islam, economic behavior.

\section{Introduction}

The linking between religious piety and the Muslim fashion industry has increasingly been a global phenomenon (Yetişer \& Genç, 2015). The instability of Islamic-ness in the veiling-fashion industry in Turkey draws out the implications of this finding for understanding of the socio-spatial work of the commodity (Gökarîksel \& Anna, 2009; Gökariksel \& McLarney, 2010). It is argued that the Islamic-ness of the commodity cannot in fact be located or fixed; it is instead best understood as a mode of insertion into socio-spatial networks. Veiling-fashion as a 
commodity enters into and becomes constitutive of the wider material and symbolic networks that enact Islamic-ness in Turkey today. Furthermore, the commodification of Islamic dress in urban Indonesia has been an important trigger for rethinking the relationship among faith, gender, and materiality. The shifting of Islamic dress in modern urban Muslim in Indonesia happened, which is being an exclusive phenomenon in 2005 and change it after (Jones, 2007, 2010).

Muslim fashion, particularly the hijab, has been a signifier of identity in Indonesia since the 1980s (Lukens-Bull, 2008). Javanese Muslim women have experienced new veiling fashion, taking it into the process of social change that constructed Javanese Muslim women in negotiating the meaning of veiling with their cultural past. This phenomena denotes the attempt of transformation of self among Javanese women, “... that the decision to wear Islamic-style clothing both effects and signifies a transformation of self for women in Java, and that this subjective transformation is informed by, and in turn contributes to, larger processes of social change occurring in contemporary Indonesia" (Brenner, 1996; Smith \& Nancy, 2007).

Meanwhile, the development of Muslim fashion industry in Indonesia has recently become the sign of religiosity through fashion. The way Muslim community consume Muslim fashion is merely due to neo-capitalist industry created the new life style through the religious symbol (Jones, 2010). However, the sign of religiosity that was brought by Muslim fashion and consumed by Muslim community has potential consideration not as a false satisfaction (Angkita, 2012; Tarlo, 2007). This term refers to the consumption of signs brought by the media; while Muslim communities in Indonesia consume Muslim fashion in order to fulfill their religious piety needs (Jafari \& Sandikci, 2016; Tarlo, 2010). This article uses the term Muslim fashion in order to make it clear that 
Muslim fashion (busana Muslim) discusses to not only about hijab or veils but also all the clothing, accessories, and tools that supported and involved in it (Hamdani, 2011). It is the common term that is used in Indonesia that Muslim fashion is more like how the people wear clothing in Muslim way. This means that when people wear clothes in Islamic way, they wear not only headscarves but also long sleeves, long pants, skirts, or dresses in order to cover their body based on Islamic teaching.

This article proposes to figure out the relation of religious piety in Muslim fashion industry. As doing brief survey, this article finds many contestations happening in this industry between identity, economic values, and religiosity (Hasan, 2009). To analyze more about those phenomena, this article seek to examine the interplay between the blooming of Muslim fashion industry and the current Islamic lifestyle in Indonesia and the role of religious piety in boosting the production and distribution within the Muslim fashion industry. Karita fashion industry has been a locus of research of this article. This article put an argument of that Muslim woman in Indonesia considered fashion as one of the symbols of piety; however some take advantage it as an economic commodity.

\section{Muslim Fashion and Millennial Designers}

In spring 2015, the prominent fashion house from Italy, Dolce \& Gabbana launched their new collection of abaya for Muslim customers. The Week (2006) informed that they also promoted this new abaya as part of their mainstream media presence company Instagram (IG) account together with their mix backstage shots and other catwalk collections. Dolce \& Gabbana as one of the most popular fashion houses in the world which usually produces high-end fashion introduced the abaya with the theme "amidst the desert dunes and skies of the Middle East, an enchanting visual story about the grace and beauty of the marvelous women of 
Arabia." Despite the exotic description, their purpose in producing this abaya arguably due to the political and cultural awareness, which noticed that the global Muslims spend on apparel was valued at $\$ 266$ billion in 2013 and projected to rise to $\$ 484$ billion by 2019 . Here is the evidence that Muslim fashion lately has grown into a luxury market and gained the special attention from the influential fashion house in the world (SayanCengiz, 2018; Stano, 2010).

Subsequently, this involvement of the luxury brand in Muslim fashion also makes this fashion industry wider and extends into the politics of culture particularly for the wealthy Arab women who had been keeping the couture houses in business since the 1970s. Since its emergence, Muslim fashion experienced a great recognition from people in the world (Qomariyah, 2016). It means many people consume this fashion, yet on the other hand it accepts the religiosity into public life. This kind of acceptance assumes a good impact in clothing industry of the countries not only in Muslim majority countries but also others. In addition, Muslim fashion has become a new commodity in fashion industry due to some investors considered this as promising market as a new line in fashion world (Hassler, 2004). For instance, so many Muslim fashion stores emerge not only from Dolce \& Gabbana but also in some big cities in the world such as Jakarta, Kuala Lumpur, even in Orlando (Huffingtonpost, 2015).

Muslim fashion which is part of fashion industry has been emerged in Indonesia since the resurgence of Islamic teaching in the last four decades. However, the development of Muslim fashion in Indonesia was begun from few decades ago, particularly from the resignation of Soeharto regime (Jones, 2010, p. 91). At this time is presumably has been the turning point of the era of freedom expression and Muslim communities in Indonesia that are freely to show their Islamic lifestyle. Due to political interest, the 
government limited the expression of religiosity in public space. It was in the early phase of the New Order regime, wearing Islamic clothing was considered a form of resistance to the state authorities.

Even in 1982, the Department of Education and Culture decided to prohibit female students of secondary educational institutions from wearing a head covering at school, basically it was considered as the basic code of school uniform (Amrullah, 2008). In a few decades of his tenure, Soeharto stressed the system of equations and equity in order to avoid potentially group that would protest his power. The restriction of wearing headscarves in public school certainly does not last forever. It was only in 1991, that the state, in an effort to co-opt the Muslim community, allowed Muslim women again to wear head coverings at schools and government offices. This changing followed the political changing of Indonesia's reformation. In 1998, Soeharto regime fell as young people and university students demonstrated in front of DPR-MPR building.

Since Islamic fashion has become popular not only with the Muslim community but also for non-Muslims, it has earned strong acceptance from people in every element. Wearing Islamic fashion is a kind of cultural shifting from traditional into modernity has change the way of thinking of urban people particularly who live in central cities. Islamic fashion that spread in society not only in the terms of social changing but also has engaged with Western social theory with economic development and cultural modernity (Smith \& Nancy, 2007). Arguably, the phenomenon in other way does not only impact the cultural changing but also the economic development that brings the Muslim society to enter the modernity. However, the changing of modernity brought some consequences for some aspects as we are reminded by urban people especially who feel that they need to exist in this kind of modern era and admit this new culture and new lifestyle. "Modernity, we are reminded, is 
multiple sign its meanings and organizations, not least of all when it comes to gender" (Jones, 2007). The gender issue in Muslim fashion often occurs into surface because women are the most community who wear hijab or headscarves. On the other hand, the discourse of Muslim fashion is not only about hijab or headscarves but also men's apparel.

The development of Muslim fashion industry in Indonesia was not apart from the involvements of Muslim fashion designers. Indonesia which has the biggest Muslim population in the world has created a lot of Muslim fashion designers since thirty years ago. However, the masterpiece of these fashion designers at that time is not too popular because their collection is limited and expensive for common people. Dian Pelangi, one of the most influential Muslim fashion designers, has created a new trend of Muslim fashion in Indonesia. For the first time, Muslim fashion was launched in Jakarta Fashion Week, the most prestigious fashion event. Dian Pelangi received this valuable chance to introduce herself and her creation into public as Muslim fashion designer. Her creations spread in her boutiques all around Indonesia. As the pioneer of Muslim fashion in Indonesia, she has written two books since 2012. Her passion in fashion world has led her to become the Muslim fashion designer in Indonesia and her influence was spread globally.

Furthermore, since such fashion exhibition as Indonesia Islamic Fashion Fair (IIFF) and Jakarta Fashion Week (JFW) were well-organized, Indonesian Muslim fashion is moving forward and it shows that many Muslim fashion designers by the time and most of them are dominated by women. This kind of fashion exhibition then becomes prestigious event for fashion designer to showcase themselves and gain the acceptance from fashion designer community and public. Some famous names that emerge from this exhibition are like Ria Miranda, Jenahara, Zaskia Sungkar, and Fitri Aulia. Each Muslim designer has her own characteristic in her 
collection; for instance, Dian Pelangi emphasizes colorful pattern in her collections and Ria Miranda brings pastel color for her masterpieces. These fashion designers are different from the leading fashion designers before, Muslim designers who usually had more knowledge about Islamic cultivation in order to make their collection appropriate with Islamic law. The acceptance from the public in Muslim fashion obviously is seen from the increasing number of Muslim fashion magazine and Muslim fashion stores from around Indonesia.

\section{Changing Fashion, Exchange Values}

Indonesia, as the biggest Muslim population in the world, experienced significant dynamic of changing in Muslim fashion development. In the past time, people wore hijab or Muslim fashion in order to make them look pious or to declare their obedience for their religion (Smith \& Nancy, 2007). When they wore Muslim fashion, it could make them feel more religious and increase their spirituality inside (Hunting \& Conroy, 2018). Its fashion obviously purposed to emphasize the identity as religious people, and people will considered them as holy and get the same meaning. Even though at the past time wearing hijab is limited for people who are considered as religious, the government is very restricted about it, yet now since people realized their freedom of expression particularly to show their religiosity into public life, wearing hijab or Muslim fashion had changed or shifted the substance.

Nowadays most of the Muslims wearing Islamic fashion are viewed not merely as religious people, yet now as a fashion choice and confirm them as modern people. Muslims nowadays see Muslim fashion merely more like material symbol and sign of modernity (Arli \& Lasmono, 2015; Farinha et al., 2017; Gökariksel \& Sekor, 2010). Muslim fashion nowadays becomes as the part of the most Muslims' lifestyle in the world who aims 
to make their selves as the modest Muslims. It is supported with the role of the media which provides the media to promote Muslim fashion as a new choice of clothing and to perform piety as well in the same time. The existence of Muslim magazine in Indonesia has the important role to build the market (Mahmood, 2011).

The users of Muslim fashion are now faced with a major intersection, which is dressed in a Muslim or Islamic way to follow the teachings of Islam or simply to follow the trend. Here is the position of Muslim fashion particularly in Indonesia is something arguable and negotiable. The shifting from past time into modernity somehow was brought by globalization impact and sometimes globalization makes people start losing their identity and try to find out themselves. The "rules of recognition", therefore, is not ran away by colonialists or the one who has power but change it into a self-recognition (Bhabha, 1985, pp. 3435). Every person based on her identity as a member of nation and an individual have self-recognition to build her own identity. In this Muslim fashion case, people are negotiating their identity in religious or modern ways or both.

Indeed Muslim fashion nowadays is unlike Muslim fashion decades ago, yet Muslims in Indonesia feel this changing and this phenomenon is quite dynamic and extraordinary. The discussion about Muslim fashion will be explained further because this new line of fashion has become a new lifestyle of Muslim people in urban community. Since it discovers as new lifestyle, it is supported by such many aspects of fashion community as magazine, fashion group or community, Muslim designers, and producer for sure; thus it makes Muslim fashion as a new promising industry (Amrullah, 2008; Brenner, 1996; Smith \& Nancy, 2007; Jones, 2007). Ultimately Muslim Fashion today is considered merely about fashion which contains religious symbol on it and a new kind of industry that brings high profit. 
As the increasing a number of people who wear Muslim fashion around the world, Muslim fashion recently gave it particular substance for them. Similar to Jones (2007) that mentioned about the stereotype of hijab is "the only women for whom headscarves were typical were older women who had completed the hajj, and they wore a gauzy, loose kerudung rather than the more opaque and close-fitting jilbab." As the changing of the era, Muslim women in Indonesia are aimed to choose to be more fashionable moreover because of their anxiety of being good Muslim and modern. However, the evidence proves that Muslim fashion is not merely about personal religiosity. When people recently feel that they finally got their freedom to express their religiosity into public sphere, it makes some of the capitalist got the idea to take an advantage of this freedom into commodity. Echoing Marx's idea that the heart of the commodity lays a magical gap between the material properties of its use value and the affective dimensions of its fetishization, dimension which give rise to exchange value (Marx, 1976, p. 319-22).

Indeed, the commodity of Muslim fashion industry extends its wings into many sectors such as textile industry, producing, manufacturing, and distributing its products through some religious activities that finally make the users of this fashion unconsciously become proud and little arrogant (Kiliçbay \& Binark, 2002; Lewis, 2007). The term of wearing into some fashion Muslims particularly that are made by such popular designers which then they make it such a big business that emphasize on brand image (Rice, 1999). The quote from Dian Pelangi, (2014) shows that a brand must have its own character and stick on it to make brand image, then it makes your product well-known and last for long time in market. This brand image also creates its position into class social meaning that when Muslims wear the products from the Muslim designer, it means that they will consider it as people who afford to buy the expensive clothes 
and make them likely into higher class social. Indeed these designers sell not only Muslim fashion but also prestige; it also created the consumption of Muslim fashion in many ways.

Where is the position of piety or religion in this commodity? So many critiques emerged in this development of Muslim fashion from many scholars and produced varies conclusion based on the paradigm they used. Jones (2007) assumes that the producers of Muslim fashion are fared well in creating the assumption of piety for the user of its fashion, stating that

In those critiques, consumers of fashionable busana Muslim are positioned as starry-eyed slaves to fashion, either imitating piety or deluded into thinking that the clothes themselves might produce piety. Yet none of these critiques addresses how women might borrow from the authority of a discourse of consumer choice or of Islam to position themselves as in control of their choices.

This new kind of paradigm brings the Muslim community into a new way of thinking and awareness of being more religious. Muslims in Indonesia is a paradox. It is because in other countries people who more acknowledgeable and wealthier they become more secular, instead in Indonesia the more acknowledgeable and wealthier people become more religious (Yuswohady, 2014). It can be concluded that nowadays the Muslim fashion in Indonesia becomes one of the biggest products that are consumed by Muslims. The higher of the income, the higher people spend their money for their need, especially fashion. The need of fashion in the last ten years has been increased, and people more consider fashion as their need to be fulfilled. Fashion Muslim recently has been changed from the stereotype related with part of devotee in a religion and become the new promising industry as well as the business in clothing life style. This kind of industry has played in political and cultural in Muslim society and reached the great amount of revenue not only in Indonesia but also globally (Rudnyckyj, 2009; Balasescu, 2011; Starrett, 1995; Yeniaras \& Akkemik, 2017). 
Magazines as one of the media provide the path for gaining the popularity for Muslim fashion from the society. The role of magazines here is clearly shifted from giving information into marketing of the Muslim fashion industry. Along with the time, the increasing of revenue of Muslim fashion industry makes the assumption that Muslim fashion the new part of religious consumerism. Producers of this industry must have plans to make it the new lifestyle of urban Muslim in Indonesia particularly. It can be concluded that the producers of this industry make Muslim fashion devotee consume it in the name of religion which can put the piety of urban Muslims and strengthen their identity into public sphere.

\section{Fashion as Commodity}

Along with the current swift of the Muslim fashion industry that happens in Indonesia, there are a lot of Muslim clothing stores in cities. One of the Muslim fashion stores that attract the attention is Karita Muslim Store. To maintain its existence, Karita continually recreates its own identity which is young, creative, and original. Since its emergence, this store has been different from other Muslim stores because it brings modernity and new faces of Muslim fashion to the market, and it survives in the middle of Muslim fashion industry development. Karita as one of the prominent Muslim fashion stores in Indonesia became the part of economic wheel that puts religiosity inside.

It is argued that Karita advertises Muslim fashion as a commodity through the various aspects of its business. Commodity here is defined as products or items that produced massively aims to fulfill the market demand. In the past time, commodity products usually contain of food, herbs and spices, or metals, yet along the time clothes became a commodity product as well. It is an important situation that people in the last ten years desire to have a choice regarding with fashion style to liberate their freedom 
of expression. Thus, the capitalist took this situation as an opportunity to create a new market of Muslim fashion bigger. Arguably, Karita promotes a Muslim brand without necessarily identifying it as a Muslim business, and a distinction that makes it possible to be defined is what it means to commodify Muslim piety in contemporary Indonesia.

The establishment of Karita indeed gave another style and choice for Muslim community in Indonesia particularly in fashion devotee. Karita as one of the Muslim fashion stores from Margaria group has been developed quite well as expected as the company which originated from batik business among other Muslim fashion store. Comparing with its competitors, for example Pands a Muslim department store that is established right across Karita Muslim Square in Yogyakarta, Pands has only two branches in Indonesia and it is quite new. Pands is quite different from Karita which focuses on one specific market while Pands has limited styles and instead serves the family market. Even though Karita developed out of the batik business, the owner aims to build a company that provides Muslim fashion which has exploded since fifteen years ago in Indonesia.

The high market demand for Muslim fashion makes Karita continue to grow until it has three stores in major cities in Indonesia (Yogyakarta, Surabaya, and Purwokerto). The growth of Karita nowadays is a proof that even though it was originally born from Batik business, it has become one of the pioneers of Muslim fashion stores which has the strong character in Indonesia. In order to deliver its character, Karita has created the slogan Gaya Muslim Muda and emphasizes it to be applied in Karita's business. The creation of its slogan afterwards made Karita has a significant market segment and its own style. Even though Karita was born from a batik company, yet its style has nothing to do with batik. The character behind Karita is mostly girly, feminine, cheerful, and sophisticated.

Subsequently, Karita applied the philosophy of Islamic business ethics to represent their existence as Muslim fashion store that does not 
only sell fashion but also bring religiosity into the company. It is in line with the vision and mission from Margaria group that their company is not only profit-oriented but also has high awareness for the society and God as well. Karita wants to be seen as a company which sells Muslim fashion using the Islamic values and brings the religiosity into its business. However the company did not force their employee to join the reciting Qur'an if they do not want it. It is just a program not an obligation. Karita negotiates the position of religion in its company either it applies Islamic business ethic as the foundation yet not exclusively close only for Muslim, it also serves and provides the clothes for non-Muslims.

Karita make its products become the part of religious commodity which provide the Muslim fashion needs. Even though Karita is the Muslim fashion store which sell the needs of Muslim, its company did not apply the Islamic values as their spirit of the company. This store puts its company as part of the industry that uses the philosophy of Islamic business ethic as its business foundation (DeLong, 2005). The complement of consumption is something that takes part in daily life that involves religious piety as the commodified object. Since Muslim fashion is strongly connected with public performance of identity and piety, those who consume it aim to exhibit their identity.

It is necessary to elaborate the relation of Karita's consumers and the commodification of religious piety using Baudrillard theory of consumer society. It is expected to be able to determine the classification of contemporary Muslims in Indonesia through their amount of purchase (Baudrillard, 1998). This type of classification defines the recent identity of Muslims and the social class of Muslims in Indonesia. This Muslim fashion industry is growing well in Indonesia due to the increasing numbers of people, especially Muslims who recently pay more attention to their appearances, aiming to be modest in Muslim fashion (Hassan \& 
Harun, 2016). The market itself creates this fashion as a new preferableto-society lifestyle. This lifestyle is related with religiosity; it brings the Muslim identity becoming stronger in society and shows the connection between religiosity and fashion.

As a Muslim store, Karita can be clearly seen that today's Muslim fashion becomes a religious commodity that is growing bigger along with the Islamic lifestyle. The link between Karita and religious consumerism is obvious with sufficient successful business that targets young people. The way of Karita sells their products with its marketing style is not putting the religious worship (sunnah or surah) as its tool of selling; it only offers the modest fashion at the time. It tries to provide what all Muslims need by producing and distributing to the society in order to maintain their business and to make people buy religious products only in Karita.

The clothing choice in Muslim fashion nowadays encourages Muslims to define their Muslim identity by exhibiting their fashion style. Ironically, their choice of Muslim fashion has less consideration for the religious piety. It is not about wearing Muslim fashion to make them more pious, yet it is about how to make their identity as modern and fashionable Muslims become stronger. Muslim in Indonesia unconsciously put themselves into fashionable Muslim categories that set the boundaries between the modest and fashionable middle-class Muslim and the highclass fashion Muslims. To support their daily life as fashionable and modest Muslims, they consume specific clothes that get a place in social classes.

\section{Commodifying Values in Global Context}

The emergence of Muslim fashion stores in Indonesia have proved that Muslim fashion is a part of religious commodification due to the involvement of religion to sell products. As many Muslim stores expand in Indonesia, the choices of fashion for Muslims improve too. Indeed, the number of Muslims who wear hijab in Indonesia has grown until Muslim 
fashion becomes a defining feature of an Islamic lifestyle. The Islamic lifestyle has increased the freedom of choice for Muslim fashion devotees to express their identity creatively. The choice of fashion varies until the time for Muslims has come to classify themselves into two Muslim fashion categories, which are called middle-class fashion Muslims and high-class fashion Muslims that determine their identity or social class in Muslim communities. Therefore, the consumption of Muslim fashion in Indonesia has become an attempt to strengthen their identity as modern and modest Muslims.

How big is the development of this industry and what else who involve in the proliferation of this industry. This section also gives the evidence that some aspects of in religion use to transaction "aims to examine the exchange aspects of religio-economic transactions, particularly where the symbols of faith are being used to market Islam-associated products" (Fealy $\&$ Sally, 2008). This article uses the data from many sectors for instance, global market, ministry of trade, and Islamic economic report. It can be concluded that Indonesia has an essential part in this development since Indonesia is the biggest Muslim population country (Iannaccone, 1998). It can be seen from the GDP (Gross Domestic Product) that Indonesia has the highest among the Muslim countries. Even the government has been very optimistic that Indonesia will be launched into a fashion Mecca for the Muslim world by 2020 .

In line with Indonesia Islamic Fashion Consortium (IIFC), the Muslim fashion industry in Indonesia has experienced significant growth since the 1990s and various factors make the Muslim fashion continues to grow. The continuity of growth is the rise in demand for Islamic fashion, growing communities like Hijabers Community hijab, Hijabers Mom, and others until the convening diverse bazaar, fashion Muslim, hijab class activities on campus, companies, recitals, or the gathering strongly 
supports the growth of this business in the country. On February 14, 2016 three Muslim fashion designers Indonesia, Zaskia Sungkar, Barli Asmara and Dian Pelangi (ZBD) have a fashion designs Muslims show together. This activity is of course an opportunity for Indonesia can be Indonesian market.

As I mentioned above that Muslim fashion is considered as promising and profitable business, it was supported by the Muslim fashion devotee from around the world (Akou, 2007; Hendar et al., 2018; Meamber et al., 2017; Rahman et al., 2017). Since religion is still being the important part of their life, so this industry will stay on its track even bigger because people nowadays are more consumptive and it is utilized by the producers to put a prestige in this fashion industry. The term prestige in fashion world used by many designers not only the high end fashion but also Muslim designer such as Dian Pelangi (2014). For example, since Muslim fashion has a huge demand from many people, the prominent designer and fashion house Dolce and Gabbana produced an abaya for their Ramadan collection in 2015.

The term of prestige here is representing the consumptive habit of Muslim community and the searching of identity which makes them into some social class. The spending capability of Muslim consumers is increasing by the time, based on the Global Islamic Economy 20142016 reported that global Muslim consumers spending on clothing and footwear have increased $11.9 \%$ to reach $\$ 266$ billion in 2013 . This makes the Muslim clothing market to be $11.9 \%$ of the global expenditure and is expected to reach $\$ 488$ billion by 2019 . Top countries with Muslim consumers clothing consumption (based on 2013 data) are Turkey (\$39.3 billion), United Arab Emirates ( $\$ 22.5$ billion), Indonesia ( $\$ 18.8$ billion), and Iran ( $\$ 17.1$ billion). The data were also supported by the Director General of Small and Medium Industries (SMI) Ministry of Industry. It 
shows that there are 20 million people in Indonesia who use the hijab. This is consistent with the development of Muslim fashion industry which is $7 \%$ every year. Additionally, from 750,000 Small and Medium Industries (SMEs) in Indonesia, Muslim fashion industry controls 30 percent the total search "Muslim fashion" in Google, $77 \%$ is apparently derived from Indonesia. Then, 16\% of which is from Malaysia and 2\% from the UK as well as India and there is 5,447 conversations per day about the veil on Twitter.

Creative industries especially Muslim fashion is quite resilient and continues to grow rapidly despite the current challenging conditions and the persistence of global economic uncertainty. The growth of the fashion industry in 2015 is expected to reach 8\%. Even the fashion industry was ranked the second after the culinary industry in Indonesia. Creative industries have contributed greatly to the GDP of up to IDR 573.5 trillion, with the support of the fashion industry's contribution as the second order of about $30 \%$ or reach 164.7 trillion after the culinary industry from 15 types of creative industries (Islamiceconomic.org, 2015). All the data here clearly show that Indonesia has a great amount in consuming fashion which Muslim fashion must have the big part on its proof from the report of Global Islamic Economy in 2014. It means Muslim fashion industry has become a new part of Indonesian Muslim's consumption associate with accomplishment of their needs of fashion and religion, and somehow it might be the reason behind its act.

\section{Conclusion}

The discourse about burgeoning of Muslim fashion in Indonesia prompts much speculation associated with Islamic revival. This phenomenon leads Muslim fashion to become an economic part of religion regarding the Muslim fashion industry. The industry of Muslim fashion has developed rapidly in the last ten years alongside with the 
growing number of Muslims who adopt Islamic lifestyle by wearing hijab in daily activities. The development of Muslim fashion industry supported by many elements, such as media (Muslim magazines), Muslim designers, Muslim communities, and Muslim fashion stores. The emergence of Muslim magazine is intended to accommodate Muslims in fashion and lifestyle needs. Supporting the growth of Islamic lifestyle, many Muslim designers appear to help Muslims express their fervor of fashion in Islamic ways, which covers their body and hair properly.

The increasing interest in Muslim fashion results in the increasing number of producers of fashion retails. To keep up with the high demand of Muslim fashion, this industry is booming and spreading to Muslim communities in Indonesia. The industry of Muslim fashion ultimately becomes one of the most promising industries in fashion retail in Indonesia and there will come a time for Indonesia to be one of Muslim fashion centers in the world. Following the success of Muslim fashion industry, numerous Muslim fashion stores have emerged all over Indonesia. One of the successful Muslim fashion stores in Indonesia is Karita that is part of the Margaria Group, Yogyakarta-based Fashion Company that started from batik and now opens several stores specializing in Muslim fashion for various target populations. With the slogan "young Muslim style”, Karita serves Muslim fashion goods for young Muslims who are considered as fashionable, modest, up to date and active people.

Karita aspires to be seen as a company that sells Muslim fashion products by utilizing Islamic values and bringing out the religiosity into its business to be not merely as personal concern. Nevertheless, Karita do not force its employees to join in their religious activities and try to respect the employees' choice of religious concern. This shows that Karita is a quite flexible company to do this kind of business. Even though this company applies some Islamic business philosophy, Karita does not sell its products 
by utilizing religious piety or Islamic teaching so that it will boost Muslims' religious piety by consuming its products. Karita as a Muslim fashion store sells the latest fashion goods that are applicable and appropriate for Muslims to wear. Thus, it can be concluded that Karita is a store that sells Muslims' needs packed in Islamic ambience. The existence of Karita is a proof that the rise of religious piety among Muslims nowadays has an important role in boosting the production and distribution of Muslim fashion as the new religious commodity.

Karita's consumers are active shoppers and have a choice to decide their own style from the occupation background, the amount of purchase, and the fervor of fashion style. In conclusion, the activeness of Karita's women varies based on their background. However, the main reason of them choosing Karita as a shopping destination is because of the collections that are always up to date and the location that is near their places. Based on the data, Karita's consumers seem to belong to middle class society who is considered as Universalist category. Karita that does not exclusively provide fashion items for Muslims, but also for non-Muslims encourages its costumers to be more open and tolerant to others.

Finally, the choice in Muslim fashion makes Muslims define their identity by showing their fashion style. It leads Muslims to willingly consume Muslim fashion in order to connect their religious piety through Muslim fashion. Thus, Muslim fashion is manifestation of commodification of religious piety for Muslim society. Indonesian Muslims directly put themselves into fashionable Muslim boxes that make the boundaries between the modest and fashionable middle Muslim and the high fashion Muslims more visible. To support their daily life as fashionable and modest Muslims, they consume the specific clothes that put them into social class. It is the proof that Muslim fashion industry in Indonesia is the tool to define Muslims identity. Consuming Muslim fashion for Muslims in the 
last ten years has an aim to make them to be part into class social or a particular Muslim group that they want based on their purchasing ability. 


\section{References}

Akou, H. M. (2007). Building a new "world fashion": Islamic dress in the twenty-first century. Fashion Theory - Journal of Dress Body and Culture, 11(4), 403-422. https://doi.org/10.2752/175174107X250226.

Amrullah, E. (2008). Indonesian Muslim Fashion Styles \& Designs. ISIM Review, 22(2).

Angkita, R. (2012). Analisis Pengaruh Bauran Pemasaran Terhadap Kepuasan dan Loyalitas Pelanggan di Karita Muslim Square Yogyakarta (Thesis). Universitas Gadjah Mada.

Arli, D., \& Lasmono, H. (2015). Are religious people more caring? Exploring the impact of religiosity on charitable organizations in a developing country. International Journal of Nonprofit and Voluntary Sector Marketing, 20(1), 38-51. https://doi.org/10.1002/nvsm.1516.

Balasescu, A. (2011). Investment, fashion and markets in the Muslim world. In Handbook of Islamic Marketing (pp. 55-69).

Baudrillard, J. (1998). The consumer society: Myths and structures. Sage Publisher.

Brenner, S. (1996). Reconstructing self and society: Javanese Muslim women and "the veil." American Ethnologist, 23(4), 673-697.

DeLong, M. (2005). Theories of Fashion. In Encyclopedia of Clothing and Fashion/V. Steele (ed.).-Detroit: Thompson/Gale, 432.

Ong, A., \& Peletz, M. G. (Eds.). (1995). Bewitching women, pious men: Gender and body politics in Southeast Asia. University of California Press.

Farinha, M. J. U. S., Bernado, L. V. M., Lopes, A. Q., Carvalho, M. D., Vasconcelos, P. E. A., Martins, L. C., \& Ruviaro, C. F. (2017). The relationship between religion interdisciplinary, habits food and economics from an approach bibliometric. Espacios, 38(12).

Fealy, G., \& Sally, W. (2008). Expressing Islam: Religious Life and Politics in Indonesia. Singapore: Institute of Southeast of Asian Studies. 
Gökarîksel, B., \& Anna, J. S. (2009). New Transnational geographies of Islamism, capitalism and subjectivity: the veiling-fashion industry in Turkey, in Muslim Societies in the Age of Mass Consumption: Politics, Culture and Identity between the Local and Global. Cambridge Scholars Publishing.

Gökariksel, B., \& McLarney, E. (2010). Muslim Women, Consumer Capitalism, and The Islamic Culture Industry. Journal of Middle East Women's Studies, 6(3), 1-18.

Gökarıksel, B., \& Sekor, A. (2010). Islamic-ness in the life of a commodity: veiling-fashion in Turkey. Transactions of the Institute of British Geographers, 35(3), 313-333.

Hamdani, D. (2011). Anatomy of Muslim Veils: Practice, Discourse and Changing Appearance of Indonesian Women. Lambert Academic Publishing.

Hasan, N. (2009). The Making of Public Islam: Piety, Agency, and Commodification on the Landscape of the Indonesian Public Sphere. Contemporary Islam, 3(3), 229-250.

Hassan, S. H., \& Harun, H. (2016). Factors influencing fashion consciousness in hijab fashion consumption among hijabistas. Journal of Islamic Marketing, 7(4), 476-494. https://doi.org/10.1108/JIMA10-2014-0064.

Hassler, M. (2004). Changes in the Indonesian clothing industry: Trade and regulation. Singapore Journal of Tropical Geography, 25(1), 64 76.

Hendar, H., Nurhayati, T., \& Sugiyarti, G. (2018). Religio-centric fashion advantage on marketing performance: The role of innovativeness and customer responsiveness. Contaduria y Administracion, 63(4). https:// doi.org/10.22201/fca.24488410e.2018.1378.

Hunting, A., \& Conroy, D. (2018). Spirituality, stewardship and consumption: new ways of living in a material world. Social Responsibility Journal, 14(2), 255-273. https://doi.org/10.1108/SRJ06-2016-0097. 
Iannaccone, L. . (1998). Introduction to the Economics of Religion. Journal of Economic Literature, 1465-1495.

Jafari, A., \& Sandikci, Ö. (2016). Introduction: Islam in consumption, marketing and markets. Islam, Marketing and Consumption: Critical Perspectives on the Intersections, 1-14. https://doi. org/10.4324/9781315797335.

Jones, C. (2007). Fashion and faith in urban Indonesia. Fashion Theory, 11(2-3), 211-231.

Jones, C. (2010). Images of Desire Creating Virtue and Value in an Indonesian Islamic Lifestyle Magazine. Journal of Middle East Women's Studies, 6(3), 91-117.

Jones, Carla. (2010). Materializing Piety: Gendered Anxieties about Faithful Consumption in Contemporary Urban Indonesia, 37(4), 617-637.

Kiliçbay, B., \& Binark, M. (2002). Consumer culture, Islam and the politics of lifestyle: Fashion for veiling in contemporary Turkey. European Journal of Communication, 17(4), 495-511. https://doi.or g/10.1177/02673231020170040601.

Lewis, R. (2007). Veils and sales: Muslims and the spaces of postcolonial fashion retail. Fashion Theory - Journal of Dress Body and Culture, 11(4), 423-442. https://doi.org/10.2752/175174107X250235.

Lukens-Bull, R. (2008). Commodification of Religion and The "Religification" of Commodities: Youth Culture and Religious Identity. In P. Kitiarsa (Ed.), Religious Commodification in Asia: Marketing Gods (pp. 220-234). New York: Routledge.

Mahmood, S. (2011). Politics of piety: The Islamic revival and the feminist subject. Princeton: Princeton University Press.

Meamber, L. A., Joy, A., \& Venkatesh, A. (2017). Fashion in consumer culture. In Routledge Handbook on Consumption (pp. 431-441). https://doi.org/10.4324/9781315675015 
Pelangi, D. (2014). Brain, Beauty, Belief,. Jakarta: Gramedia.

Qomariyah, F. (2016). Women, Islam and Economic Activity: Examining the Religious Ethics of Muslim Business Women in Indonesia (Thesis). Universitas Gadjah Mada.

Rahman, M., Albaity, M., \& Maruf, B. (2017). The Role of Religiosity on the Relationship Between Materialism and Fashion Clothing Consumption Among Malaysian Generation Y Consumers. Social Indicators Research, 132(2), 757-783. https://doi.org/10.1007/ s11205-016-1310-9.

Rice, G. (1999). Islamic Ethics and the Implications for Business. Journal of Business Ethics, 18(4), 345-358.

Rudnyckyj, D. (2009). Spiritual economies: Islam and neoliberalism in contemporary Indonesia. Cultural Anthropology, 24(1), 104-141.

Sayan-Cengiz, F. (2018). Eroding the symbolic significance of veiling? the Islamic fashion magazine Âlâ, consumerism, and the challenged boundaries of the Islamic neighborhood. New Perspectives on Turkey, 58, 155-178. https://doi.org/10.1017/npt.2018.9.

Smith, H., \& Nancy, J. (2007). Javanese Women and the Veil in PostSoeharto Indonesia. The Journal of Asian Studies, 66(2), 389-420.

Stano, S. (2010). Under the veil of media. Semiotics of the hijab between the East and the West (Vol. 5-6).

Starrett, G. (1995). The political economy of religious commodities in Cairo. American Anthropologist, 97(1), 51-68.

Tarlo, E. (2007). Islamic cosmopolitanism: The sartorial biographies of three Muslim women in London. Fashion Theory - Journal of Dress Body and Culture, 11(2-3), 143-172. https://doi. org/10.2752/136270407X202727.

Tarlo, E. (2010). Hijab online: The fashioning of cyber islamic commerce. Interventions, 12(2), 209-225. https://doi.org/10.1080/136980 1X.2010.489695. 
Yeniaras, V., \& Akkemik, K. A. (2017). Materialism and Fashion Consciousness: The Moderating Role of Status Consumption Tendencies and Religiosity. Journal for the Scientific Study of Religion, 56(3), 498-513. https://doi.org/10.1111/jssr.12363.

Yetişer, B., \& Genç, B. (2015). When faithful consumption meets modernism: A review of consumption practices in Turkey. In Islamic Perspectives on Marketing and Consumer Behavior: Planning, Implementation, and Control (pp. 40-71). https://doi. org/10.4018/978-1-4666-8139-2.ch003.

Yuswohady. (2014). Marketing to The Middle Class Muslim. Jakarta: Gramedia Pustaka Utama. 
Vol. 3 No. 2, May - August 2018 


\section{Shirkah Author Guidelines}

Shirkah currently offers two routes to submit manuscripts. We highly recommend to submit the articles which are made using OJS (Open Journal System). Feel free register as author soon through visiting http:// shirkah.or.id/index.php/home/user/register. The authors may directly send their manuscripts, along with their resume, to shirkahiainsurakarta@ gmail.com. Please prepare your manuscripts, using following guidelines:

1. Manuscript must be written in English. Submitted articles should not have been published or be under review for publication with another journal.

2. Manuscript's length is about $15-20$ pages, typed in one-half spaced on A4-paper size.

3. Manuscript must include an $150-200$ word abstract and keywords.

4. Manuscript must be arranged as follows: Title, Name of Author, E-mail address, Abstract, Keywords, Introduction (including method if any), Discussion, Conclusion, References.

5. Manuscript's titles not more than ten words.

6. Manuscript must be submitted in Microsoft Word or RTF.

7. Arabic words should be transliterated according to the style of International Journal of Middle Eastern Studies.

8. Manuscript references are preferably derived from the up-to-date references.

9. The author's resume should be submitted separately, consisting of at least full name, institutional address, phone number, areas of studies, and recent publications (if any).

10. Shirkab use APA Style 6th edition (2010) as reference format writing. We suggest the use of a reference manager software such as Mendeley, Zotero, and Endnote at templating the citation style. APA Style to be used is as follows: 


\section{Book with single author}

Swann, G. M. Peter. (2014). The Economics of Innovation an Introduction. Cheltenhum \& Northampton: Edward Elgar.

in-text citation: (Swann, 2014)

\section{Articles in reference books}

Alatas, S. F. (2006). Islam and the Science of Economics in Abu Rabi', I.M. The Blackwell Companion to Contemporary Islamic Thought. USA: Willey-Blackwell (pp. 587-606).

in text citation: (Alatas, 2006)

\section{E-Book}

Hackett, Rosalind (2007). "Religous Dimentions of War and Peace: Introduction.” Dalam Gerrie ter Haar dan Yoshio Tsuruoka (Ed.), Religion and Society: An Agenda for the 21st Century (h. 3-6). Retrieved from http:// brill.nl.

in text citation: (Hackett, 2006)

\section{Master's thesis, from a commercial database}

McNieI, D. S. (2006). Meaning through narrative: A personal narrative discussing growing up with an alcoholic mother (Master's thesis). Available from ProQuest Dissertations and Theses database. (UMI No. 1434728)

in text citation: (Mc Niel, 2006)

\section{Doctoral dissertation, from an institutional database}

Adams, R. J. (1973). Building a foundation for evaluation of instruction in higher education and continuing education (Doctoral dissertation). Retrieved from http://www.ohiolink.edu/etd/

in text citation: (Adams, 1973) 


\section{Doctoral dissertation, from the web}

Bruckman, A. (1997). MOOSE Crossing: Construction, community, and learning in a networked virtual world for kids (Doctoral dissertation, Massachusetts Institute of Technology). Retrieved from http:/www-static. cc.gatech.edu/--asb/thesis/

in text citation: (Bruckman, 1997)

\section{Journal article with No DOI}

Bourkhis, K., and Nabi, M. S. (2013). Islamic and conventional banks' soundness during the 2007-2008 financial crisis. Journal Metrics, 22(2), 68-77.

in-text citation: (Bourkhis \& Nabi, 2013).

\section{Journal article with DOI}

Ichwan, M. (2012). The Local Politics Of Orthodoxy: The Majelis Ulama Indonesia in the Post-New Order Banten. Journal Of Indonesian Islam, 6(1), 166-194. doi:http://dx.doi.org/10.15642/JIIS.2012.6.1.166-194

In text citation : (Ichwan, 2012)

\section{Abstract as citation}

Hasan, N. (2012). Islamist Party, Electoral Politics And Da'wah Mobilization Among Youth : The Prosperous Justice Party (PKS) in Indonesia. Journal of Indonesian Islam, 6(1), 17-47. Abstract from http:// jiis.uinsby.ac.id/index.php/jiis/article/view/97

in text citation : (Hasan, 2012)

\section{Mass media article}

Sahal, Akhmad (2014, March 2). Kiai Sahal dan Realisme Fikih.Tempo Magazine, p. 120.

in text citation : (Sahal, 2014) 


\section{Research report}

Fisher, B. S., Cullen, F. T., \& Turner, M. G. (2000). The Sexual Victimization of College Women. Research Report.

in text citation : (Fisher, Cullen, Turner, 2000)

\section{Monograph}

Routray, Bibhu Prasad (2013), National Security Decision-Making in India (RSIS Monograph No. 27). Singapura: Rajaratnam School of International Studies.

in text citation : (Routray, 2013)

\section{Proceeding article}

Sudibyakto, Hizbaron, D.R., \& Jati, R (Ed.) (2009), Proceeding International Seminar Disaster Theory, Research and Policy. International seminar held by Sekolah Pascasarjana, Universitas Gajahmada, Yogyakarta, 8-9 Desember 2009.

in text citation : (sudibyakto and Jati, 2009)

\section{Paper conference/seminar/symposium}

Janutama, Herman Sinung (2011). "Kraton dan Hubungan Antar Agama." Paper presented in Seminar Kraton dan Panatagama held by Center for the Study of Islam and Social Transformation (CISForm), Yogyakarta, 17 November.

in text citation :(Janutama, 2011)

\section{Online article in web}

Shiva, (2006, February). Bioethics: A Third World Issue. Native-web. Diperoleh dari http://www.nativeweb.org/ pages/legal/shiva.html

in text citation : (Shiva, 2006) 


\section{Online research report}

Kessy, S. S. A., \& Urio, F M. (2006). The contribution of microfinance institutions to poverty reduction in Tanzania (Research Report No. 06.3). Retrieved from Research on Poverty Alleviation website: http://www. repoa.or.tz /documents_storage/Publications/Reports/06.3_Kessy_and_ Urio.pcif

in text citation : (kessy and urion, 2006)

\section{Holy book}

Qur an, $2(25)$

In text citation : (Q. al-Baqarah 2:25).

\section{Encyclopaedia}

Graycar, Adam (1992). Social Welfare Policy. Dalam Mary Hawkesworth dan Maurice Kogan (Ed.), Encyclopedia of Government and Politics (Vol. 1). London: Routledge.

in text citation : (Graycar, 1992)

\section{Interview}

Sultan Hamengkubuwono X (interview, 2011, April 19)

in text citation: (Hamengkubuwono, 2011)

\section{Documentary film}

Steijlen, Fridus (2008). A Day in the Life of Indonesia [documentary film, 58 minutes]. Leiden: KITLV Press.

in text citation : (Steijlen, 2008) 
Vol. 3 No. 2, May - August 2018 